DOI: 10.46340/eppd.2020.7.6.35

\title{
Taras Fortuna
}

ORCID ID: https://orcid.org/0000-0002-7012-3036

Frankivsk District Court of Lviv, Ukraine

\section{RECOGNITION AND ENFORCEMENT \\ OF COURT DECISIONS OF FOREIGN COURTS \\ IN UKRAINE TAKING INTO ACCOUNT \\ THE PRACTICE OF THE EUROPEAN COURT OF HUMAN RIGHTS}

\author{
Тарас Фортуна \\ Франківський районний суд м. Львова, Україна

\section{ВИЗНАННЯ ТА ВИКОНАННЯ РІШЕНЬ ІНОЗЕМНИХ СУДІВ В УКРАЇНІ 3 ВРАХУВАННЯМ ПРАКТИКИ СВРОПЕЙСЬКОГО СУДУ 3 ПРАВ ЛЮДИНИ}

\begin{abstract}
The task of every democratic state is to provide persons seeking justice with maximum guarantees for the organization and administration of justice. So the need arouses to study the right to a fair trial in the context of studying the recognition and enforcement of decisions of foreign courts. The right to a fair trial is a fundamental human right in the democracy and at the same time it is an element of the rule of law, which is one of the fundamental principles in a democratic society. The article has provided a detailed theoretical analysis of the procedure for recognition and enforcement of decisions of foreign courts in Ukraine, taking into account the practice of the European Court of Human Rights. According to the results of the research, it has been concluded that there is the need to apply the pratcice of the European Court of Human Rights to the procedure of recognition and enforcement of decisions of foreign courts in Ukraine, thus to further improve the legislative mechanism for recognition and enforcement of such decisions.
\end{abstract}

Keywords: European Court of Human Rights, court decision, recognition of a foreign court decision, execution of a foreign court decision, right to a fair trial.

Завдання кожної демократичної держави полягає в забезпеченні особам, які звертаються за судовим захистом, максимальних гарантій щодо організації і здійснення правосуддя, що зумовлює необхідність дослідження питання права на справедливий суд в контексті вивчення питання визнання та виконання рішень іноземних судів.

В науковій літературі відсутній єдиний підхід до розуміння сутності та значення права на справедливий судовий розгляд. Найбільш прийнятним вбачається таке розуміння сутності права на справедливий судовий розгляд: по-перше, як суб'єктивне право в контексті концепції прав людини; по-друге, як система мінімальних вимог, дотримання яких має забезпечити держава при зверненні особи до суду, тобто як позитивне зобов'язання держави у сфері відправлення правосуддя в цивільних справах ${ }^{1}$.

Отже, право на справедливий судовий розгляд належить до позитивних прав людини, які визначаються як права, що закріплюють позитивний аспект свободи, і їх реалізація неможлива без відповідної забезпечувальної діяльності з боку державних інституцій ${ }^{2}$. Разом $з$ цим пов'язане

\footnotetext{
${ }^{1}$ Ткачук, О. С. (2016). Проблеми реалізації судової влади у цивільному судочинстві. Харків: Право, 128.

${ }^{2}$ Христова, Г. О. (2013). Доктрина позитивних зобов'язань держави щодо прав людини:основні етапи формування. Державне будівництво та місиеве самоврядування, 26, 22.
} 
друге розуміння права на справедливий судовий розгляд як позитивного зобов'язання держави забезпечити мінімальні гарантії процедурної справедливості при розгляді судових справ у національних судах.

Таким чином, право на справедливий судовий розгляд $є$ основоположним правом людини в демократичній державі та одночасно елементом принципу верховенства права, який $є$ одним із основоположних принципів у демократичному суспільстві. Іншими словами слід зазначити, що право на справедливий судовий розгляд є процесуальним правом людини, функція якого може бути зведена до двох основних положень: зазначене право $\epsilon$ правом для захисту інших прав, а також воно має власну самодостатню цінність як складова принципу верховенства права.

Наведене є особливо важливим у контексті європейського вибору України, визнання та взяття на себе зобов'язань гарантувати європейські цінності, провідне місце серед яких належить праву на справедливий судовий розгляд, проголошеного в чималій кількості міжнародних актів, основним 3 яких є Конвенція про захист прав людини і основоположних свобод (далі - СКПЛ) ${ }^{1}$.

Слід нагадати, що Україна стала членом Ради Свропи 9 листопада 1995 року, а Конвенція про захист прав і основних свобод 1950 року була ратифікована Верховною Радою України Законом України від 17 липня 1997 року № 475/97-ВР.

Право на справедливий судовий розгляд закріплено у Європейській конвенції про захист прав людини, а саме у п. 1 ст.6 закріплено право кожного на справедливий і публічний розгляд його справи упродовж розумного строку незалежним і безстороннім судом, встановленим законом, який вирішить спір щодо його прав та обов'язків цивільного характеру.

Як вірно з цього приводу вважає В.В. Лутковська, що одним із наріжних каменів Конвенції $€$ стаття 6 , яка гарантує право особи на справедливий судовий розгляд.

Крім цього, унікальність Конвенції полягає в тому, що нею ж створений і механізм контролю, який одночасно є органом, який має право тлумачити Конвенцію, - Свропейський суд з прав людини. Завдяки цьому, а також завдяки розширеному тлумаченню положень Конвенції Судом Конвенція має назву «живого організму», який $з$ часом не втрачає актуальності ${ }^{2}$.

Європейський суд з прав людини - це міжнародний судовий орган, юрисдикція якого поширюється на всі держави-члени Ради Свропи, що ратифікували Конвенцію про захист прав людини і основоположних свобод, та включає всі питання, які стосуються тлумачення і застосування цієї Конвенції у міждержавних справах і справах за заявами окремих осіб ${ }^{3}$.

Призначення Європейського суду полягає у «вирівнюванні» стандартів і гарантій захисту прав людини в усіх державах-учасницях Конвенції і формуванні єдиного європейського правового простору в сфері захисту прав людини і основоположних свобод ${ }^{4}$.

У правомірності обраної позиції можна пересвідчитися, проаналізувавши рішення Європейського суду з прав людини, який є єдиним органом, уповноваженим тлумачити положення Конвенції, діяльність якого й сприяє розробці стандарту «процесуальної справедливості» 5 .

Так, Україна ратифікувавши Конвенцію про захист прав людини та основоположних свобод 1950 року і визнала над собою юрисдикцію Європейського суду з прав людини та обов'язковість прийнятих ним рішень.

У рішеннях Європейського суду з прав людини (далі - ЄСПЛ) щодо тлумачення п.1 ст.6 ЄКПЛ одним із елементом верховенства права визнаються така складова права на справедливий судовий розгляд як обов'язковість виконання судових рішень.

Таким чином, право на справедливий суд $є$ невід’ємним процесуальним правом кожного, чиї права порушені, не визнані чи оспорюються, та гарантується разом з правом доступу до правосуддя та забезпеченням його ефективності, в тому числі особам, що звертаються до суду із заявою про визнання та виконання рішень іноземних судів.

\footnotetext{
${ }^{1}$ Ткачук, О. С. (2016). Проблеми реалізації судової влади у цивільному судочинстві. Харків: Право, 6

2 Лутковська, В. В. (2006). Застосування вимог Конвенції «Про захист прав і основних свобод людини до процесу виконання рішень національних судів». Вісник центру суддівських студій.

<http://www.judges.org.ua/article/Vesnik7_8.pdf>. (2020, листопад, 11).

${ }^{3}$ Ільков, В. В. (2017). Практика Свропейського суду з прав людини як джерело права у адміністративному судочинстві: загальні засади. Наше право, 2, 86.

${ }^{4}$ Анцупова, Т. (2013). Забезпечення послідовності прецедентного права Європейського суду з прав людини: роль Великої палати. Право України, 10, 163.

5 Ткачук, О. С. (2016). Проблеми реалізації судової влади у циивільному судочинстві. Харків: Право, 34. 
Оскільки виконання рішень національних судових органів, що набули законної сили вважається елементом права на справедливий судовий розгляд, то, на нашу думку, можливим $\epsilon$ поширення положень ЄКПЛ та практики ЄСПЛ на процедуру визнання та виконання рішень іноземних судів в Україні.

У ст. 17 Закону України «Про виконання рішень та застосування практики Європейського суду 3 прав людини» від 23.03.2006 року йдеться, що суди застосовують при розгляді справ Конвенцію та практику Суду як джерело права ${ }^{1}$. Однак ні конкретних роз'яснень вищих судових інстанцій, ні чіткої доктринальної позиції щодо можливості застосування положень, що містяться у рішеннях ЄСПЛ при вирішенні національними судами питання про визнання та виконання рішень іноземних судів, на сьогодні немає.

ЄСПЛ неодноразово висловлювався щодо застосування п. 1 ст. 6 ЄКПЛ до інституту визнання та виконання рішень іноземних суддів у цивільних справах.

Зокрема, у рішенні в справі «Hornsby v. Greece» ЄСПЛ вказав, що визнання та виконання рішення, винесеного будь-яким судом, повинно розглядатися як невід'ємна частина судового розгляду у контексті п. 1 ст. 6 ЄКПЛ ${ }^{2}$.

У рішенні в справі «McDonald v. France» ЄСПЛ вперше було зазначено, що п. 1 ст. 6 СКПЛ має застосовуватися як до рішень національних судів, так і до визнання та виконання рішень іноземних судів $^{3}$. 3 прийняття даного рішення ЄСПЛ у своїй практиці виходячи із тлумачення п. 1 ст. 6 СКПЛ почав і визнавати право особи на визнання та виконання рішень іноземних судів поряд із вимогою виконання рішень національних судів, як процесуальною складовою права на справедливий судовий розгляд у контексті п. 1 ст. 6 ЄКПЛ.

Крім цього, у справі «McDonald v. France» ЄСПЛ покладався на судове рішення, винесене раніше, а саме у справі «Hornsby v. Greece», що для провадження в тій самій державі, ефективне виконання ухваленого рішення є невід'ємною частиною «судового розгляду» 3 метою гарантування справедливого судового розгляду відповідно до статті 6 ЄКПЛ.

У подальшій практиці ЄСПЛ відстежується позиція, що відмова у виконанні рішення іноземного суду, яке було визнане національним судом, становить собою порушення права на доступ до суду у контексті п. 1 ст. 6 ЄКПЛ (Рішення в справі «Vrbica v. Croatia»). За заявою боржника, було прийнято рішення національним судом, яким було визнано примусове стягнення за визнаним рішенням іноземного суду на користь заявника недопустимим, оскільки десяти річний строк для здійснення примусового виконання закінчився. ЄСПЛ визнав таким, що обмежує доступ до суду та $€$ непропорційним меті обмеження, положення національного законодавства, відповідно до якого визнання рішення іноземного суду та звернення до відповідних державних органів із заявою про його примусове виконання не зупиняло перебіг загального строку, встановленого національним законодавством для звернення рішення іноземного суду до примусового виконання. За цих обставин відмова національного суду дозволити виконання визнаного іноземного рішення, яке винесене на користь заявника, порушила принцип пропорційності і тим самим порушила саму суть його права на доступ до суду. Відповідно, було порушення пункту 1 статті 6 Конвенції 4

У рішенні в справі «Jovanoski v. the Former Yugoslav Republic of Macedonia» ССПЛ констатував порушення права заявника на доступ до суду, через те, що державою не вдалося вжити адекватних та ефективних заходів з метою забезпечення виконання рішення суду, а тому мало місце порушення права особи на доступ до суду через невиконання рішення суду ${ }^{5}$.

Слід зауважити те, що ЄСПЛ також пов'язує зобов' язання держави щодо визнання та виконання рішень іноземних судів із позитивним зобов'язанням держави, які випливають з міжнародних договорів щодо визнання та виконання рішень іноземних судів. Зокрема урішенні в справі

\footnotetext{
1 Закон про виконання рішень та застосування практики Європейського суду з прав людини, 2006, Ст. 260 (Верховна Рада України). Відомості Верховної Ради України, 30.

${ }^{2}$ Europenian Court of Human Right (1997). «Hornsby v. Greece», 19 March 1997, par. 40, Reports of Judgements and Decisions 1997-II <http://hudoc.echr.coe.int/eng?i=001-58020>. (2020, листопад, 11).

${ }^{3}$ Europenian Court of Human Right (2004). «McDonald c. France», app. no. 18648/04, 29 April 2004.

<http://hudoc.echr.coe.int/eng?i=001-87756>. (2020, листопад, 11).

${ }^{4}$ Europenian Court of Human Right (2010). «Vrbica v. Croatia», app. no. 32540/02, 01 April 2010.

<http://hudoc.echr.coe.int/eng?i=001-98057>. (2020, листопад, 11).

${ }^{5}$ Europenian Court of Human Right (2010). "Jovanoski v. the Former Yugoslav Republic of Macedonia”, арр. по. 31731/03, 07 January 2010. <http://hudoc.echr.coe.int/eng?i=001-96603>. (2020, листопад, 11).
} 
«Romanczyk v. France» ЄСПЛ звернув увагу на необхідність дотримання зобов’язань щодо визнання та виконання рішень іноземних судів, що випливають із міжнародних договорів та Нью-Йоркської конвенції про визнання і приведення до виконання іноземних арбітражних рішень від 20.06.1956 р., чим було у даному рішенні ЄСПЛ констатовано порушення п. 1 ст. 6 ЄКПЛ ${ }^{1}$.

Крім цього, у рішенні в справі «Matrakas and Others v. Poland and Greece» ССПЛ зазначає, що відповідно до Нью-Йоркської конвенції про визнання і приведення до виконання іноземних арбітражних рішень від 20.06.1956 р. обов'язок діяти лежить не лише на заявникові, однак i на державі, на яку покладено зобов'язання у сприянні заявникові у провадженні. Відмова діяти 3 необхідною ретельністю з боку державних органів, відповідальних за виконання рішень, може свідчити про порушення п. 1 ст. 6 ЄКПЛ ${ }^{2}$.

ЄСПЛ також вказує на необхідності дотримуватися вимог розумності строків судового розгляду у контексті справ про визнання та виконання рішень іноземних судів (Рішення в справі «K. v. Italy»), де зазначено, що п. 1 ст. 6 ЄКПЛ є застосовним і до гарантії розумного строку судового розгляду до проваджень щодо визнання та виконання рішень іноземних судів. ЄСПЛ було визнано у даній справі порушення вимоги розумності строків судового розгляду, адже провадження щодо звернення рішення іноземного суду до виконання тривало понад вісім років ${ }^{3}$.

Слід також звернути увагу на рішенні в справі «Saccoccia v. Austria», де ЄСПЛ зазначає, що хоча гарантії п. 1 ст. 6 ЄКПЛ мають поширюватися і на провадження у справах про виконання рішень іноземних судів, проте застосування цієї статті до даного виду проваджень є специфічним. ССПЛ зазначає, що публічність розгляду справи становить важливу гарантію права на справедливий судовий розгляд у контексті п. 1 ст. 6 ЄКПЛ. ${ }^{4}$

Окрему увагу слід звернути на те, що ЄСПЛ поширює гарантії п. 1 ст. 6 ЄКПЛ і на провадження у міжнародному комерційному арбітражі, оскільки такі рішення прирівнюються до рішень національних суддів, що підлягають виконанню, про що зазначено у рішенні в справі «Regent Company v. Ukraine» ${ }^{5}$.

Особливу увагу слід приділити рішенню в справі «Pellegrini v. Italy». Зокрема на те, що виконанню підлягало рішення суду держави, яка не ратифікувала ЄКПЛ (мова йде про Ватикан). Однак завдання ЄСПЛ не полягало у перевірці того, чи судова процедура церковними судами Ватикану відповідала ст. 6 ЄКПЛ. Натомість ЄСПЛ мав перевірити, чи італійські суди, перш ніж приймати рішення про виконання рішення про розірвання шлюбу, належним чином переконалися, що відповідне провадження виконало гарантії ст. 6 ЄКПЛ. ЄСПЛ пояснює тим, що перевірка такого роду справи $є$ необхідною, коли рішення, стосовно якого вимагається примусове виконання, надходить від судів країни, яка не застосовує Конвенцію, і особливо необхідна, коли наслідки ухвалення такого рішення мають важливе значення для сторін. ЄСПЛ по обставинах даної справи зазначив, що італійські суди не надали особливого значення факту, що заявниця не мала можливості перевірити докази, надані їі колишнім чоловіком, а саме покази свідків. Суд повторно наголосив, що право на змагальний процес, який є одним із елементів справедливого слухання у значенні пункту 1 статті 6 ЄКПЛ, означає, що кожна сторона судового розгляду, чи то в кримінальній, чи то в цивільній справі, повинна мати можливість мати такі знання щоб висловити свої погляди на подані докази чи зауваження, які подані з метою впливу на рішення суду. Крім цього, на думку ЄСПЛ заявнику слід при розгляді справи було надати можливість скористатись допомогою адвоката, якщо вона висловить про таке бажання. Внаслідок чого ЄСПЛ вважав, що заявника було викликано до церковного суду, не знаючи, про що йдеться у справі. За цих обставин ЄСПЛ вважав, що італійські суди порушили свій обов'язок перед тим, як приймати рішення про виконання рішення церковного суду Ватикану, мали перевірити чи заявнику забезпечено право

\footnotetext{
${ }^{1}$ Europenian Court of Human Right (2010). «Romanczyk c. France», app. no. 7618/05, 18 November 2010. <http://hudoc.echr.coe. int/eng?i=001-101763>. (2020, листопад, 11).

${ }^{2}$ Europenian Court of Human Right (2013). «Matrakas and Others v. Poland and Greece», app. no. 47268/06, 07

November 2013. <http://hudoc.echr.coe.int/eng?i=001-127812>. (2020, листопад, 11).

${ }^{3}$ Europenian Court of Human Right (2010). «K. v. Italy», app. no. 38805/97, 20 July 2004.

<http://hudoc.echr.coe.int/eng?i=001-61924>. (2020, листопад, 11).

${ }^{4}$ Europenian Court of Human Right (2010). «Saccoccia v. Austria», app. no. 69917/01, 18 December 2008.

<http://hudoc.echr.coe.int/eng?i=001-90342>. (2020, листопад, 11).

${ }^{5}$ Europenian Court of Human Right (2010). «Regent Company v. Ukraine», no. 773/03, 03 April 2008.

<http://hudoc.echr.coe.int/eng?i=001-85681>. (2020, листопад, 11).
} 
на реалізацію справедливого суду у провадженні за канонічним законодавством. На основі цих фактів у даній справі було констатовано порушення п. 1 ст. 6 ЄКПЛ ${ }^{1}$.

Проаналізувавши рішення ЄСПЛ щодо застосування ст. 8 ЄКПЛ, ст. 14 ЄКПЛ та ч. 1 ст. 1 Першого протоколу до ЄКПЛ на інститут визнання та виконання рішень іноземних суддів у цивільних справах, то такі не мають поширеного характеру, однак можна взяти до уваги наступні рішення.

Зокрема, у справі «Wagner and J. M. W. L. v. Luxemburg» ССПЛ констатував порушення п. 1 ст. 6 ЄКПЛ, ст. 8 ЄКПЛ та ст. 14 ЄКПЛ, взятої у поєднанні з ст. 8 ЄКПЛ національними судами під час відмови у визнанні та виконанні рішення іноземного суду. Зокрема ЄСПЛ зазначив, що суди Люксембурга не забезпечили заявникам ефективного розгляду їх справи, а відтак не спромоглися гарантувати право на справедливий судовий розгляд, передбачене ч. 1 ст. 6 Конвенції, а тому суд постановив, що мало місце порушення цієї статті. ССПЛ відзначив, що в даній справі інтереси дитини повинні мати пріоритет у справах такого роду, не можна було об'єктивно виправдати нехтування юридичного зв'язку, що виник між заявниками на законних підставах у Перу і цей зв'язок відповідав поняттю сімейного життя у сенсі ст. 8 ЄКПЛ, а тому суд постановив, що мало місце порушення цієї статті. ЄСПЛ також не знайшов виправдання для такої дискримінації, особливо з огляду на те, що за якийсь час до подій у справі у Люксембурзі безперешкодно визнавались рішення щодо усиновлення, ухвалені в Перу, навіть якщо усиновителями були неодружені особи. Отже, така особа змушена була зазнавати гіршого ставлення, тому що рішення щодо іії усиновлення не було визнано у Люксембурзі. Відтак ЄСПЛ постановив, що мало місце порушення ст. 14 Конвенції, взятої у поєднанні із ст. 8 ЄКПЛ 2 .

Слід також звернути увагу на рішенні в справі «X v. Latvia», де ЄСПЛ вважав, що у даній справі відмова взяти до уваги твердження заявника, яке базувалося на висновках, наданих спеціалістом, які могли б розкрити можливого існування серйозного ризику для повернення дитини за змістом статті 13 (b) Гаазької конвенції про цивільно-правові аспекти міжнародного викрадення дітей від 25 жовтня 1980 року, що суперечить вимогам статті ст. 8 ЄКПЛ, а тому у даній справі заявниця зазнала непропорційного втручання в їі право на повагу до свого сімейного життя, оскільки процес прийняття рішень в рамках національного законодавства не дотримався процесуальних вимог, притаманних ст. 8 СКПЛ, оскільки місцевий суд не здійснив ефективного розгляду тверджень заявниці за статтею 13 (b) Гаазької конвенції про цивільно-правові аспекти міжнародного викрадення дітей від 25 жовтня 1980 року. Виходячи із зазначеного, мало місце порушення ст. 8 ЄКПЛ ${ }^{3}$. У даному рішенні ЄСПЛ було взято перш за все інтереси дитини, оскільки процесуальна справедливість, закріплена пунктом 2 статті 8 Закону Конвенція передбачає, що національні суди повинні належним чином поважати спірні вимоги, подані сторонами у світлі статті 13 (b) Гаазька конвенція.

Також було взято ще інтереси дитини у справі «Šneersone and Kampanella v. Italy», де ЄСПЛ повторно вказав на порушення статті 8 ЄКПЛ через рішення італійських судів про повернення дитини до Італії. ССПЛ зазначив, що він має компетенцію встановити, чи італійські суди, застосовуючи та тлумачачи положення цієї Конвенції та Регламенту, забезпечили гарантії, викладені у статті 8 Конвенції, особливо враховуючи найкращі інтереси дитини. Крім цього, має мати на увазі, що Гаазька конвенція про цивільно-правові аспекти міжнародного викрадення дітей від 25 жовтня 1980 року є по суті інструментом процесуального характеру, а не договором про права людини, що захищає осіб на об’єктивній основі пославшись на рішення «Neulinger and Shuruk v. Switzerland» ${ }^{4}$.

У рішенні в справі «Mennesson v. France» ССПЛ вважав, що держава у даній справі, створюючи перешкоду як для визнання, так і для встановлення у національному праві зв'язку спорідненості 3 біологічним батьком, вийшла за межі, дозволені для можливості розсуду та надав перевагу інтересам дітям під час звуження таких прав. 3 цих причин ЄСПЛ було зроблено висновок, що право

\footnotetext{
${ }^{1}$ Europenian Court of Human Right (2001). «Pellegrini v. Italy», 20 July 2001, Reports of Judgments and Decisions 2001-VIII. <http://hudoc.echr.coe.int/eng?i=001-59604>. (2020, листопад, 11).

${ }^{2}$ Europenian Court of Human Right (2007). «Wagner and J. M. W. L. v. Luxemburg», app. no. 76240/01, 28 June 2007. <http://hudoc.echr.coe.int/eng?i=001-81328>. (2020, листопад, 11).

${ }^{3}$ Europenian Court of Human Right (2007). «Xv. Latvia» app. no.27853/09, 26 November 2013.

<http://hudoc.echr.coe.int/eng?i=001-138992>. (2020, листопад, 11).

${ }^{4}$ Europenian Court of Human Right (2007). «Šneersone and Kampanella v. Italy», app. no. 14737/09, 12 July 2011.

<http://hudoc.echr.coe.int/rus?i=001-105624>. (2020, листопад, 11).
} 
дітей на повагу до приватного життя було порушено відповідно до ст. 8 ЄКПЛ, а право на повагу до сімейного життя таких батьків не було порушено ${ }^{1}$.

Приділяючи увагу дотриманню прав дітей, ЄСПЛ урішенні в справі «Pini and Others v. Romania» прийшов до висновку про порушення п. 1 ст. 6 СКПЛ щодо невиконання рішення суду, однак порушення ст. 8 ЄКПЛ права на повагу до приватного та сімейного життя заявників не визнав та зазначив, що заявники не користуються абсолютним захистом даного права, оскільки інтереси дітей мали протилежні інтереси та інтереси дітей мають більше значення у даній справі, а тому в даному випадку принцип пропорційності було дотримано 2.

У рішенні в справі «Negrepontis-Giannissis v. Greece» ЄСПЛ не викликало сумнівів, що приватне та сімейне життя заявника було порушене відмовою грецького суду визнати його усиновленням, що, на і думку ЄСПЛ стало безперечним втручанням у право захищене ст. 8 СКПЛ. ЄСПЛ вважає, що підстави вказані судом для відмови увизнанні усиновлення заявника, не відповідали необхідній соціальній потребі. ЄСПЛ вказав, що мета відмови у визнанні рішення, на яку посилався уряд держави не може вважатися законною. Тлумачення концепції щодо публічного порядку не повинно здійснюватися довільно та непропорційно. ССПЛ взявши до уваги покликання суду щодо прийняття на відмову від виконання іноземного рішення та виходячи щодо цього з позиції статті 8 ЄКПЛ, вважав, що принцип пропорційності у даній справі не був дотриманий і щодо п. 1 ст. 6 ЄКПЛ. Також ЄСПЛ вказав, що відмова національних судів визнати обгрунтоване рішення іноземного суду про усиновлення, а також і статус заявника як спадкоємця, що позбавило особу права на спадщину після смерті усиновителя, внаслідок чого відбулось втручання у право заявника на мирне користування майном у контексті п.1 ст.1 Першого протоколу до ЄКПЛ ${ }^{3}$. Отже у даному рішенні суд Греції не визнавши американського рішення про усиновлення, порушив права заявника відповідно до вражаючої кількості положень Конвенції: право на сімейне життя (ст. 8), а також право на недискримінацію при здійсненні права, передбачені Конвенцією (ст. 14), право власності (ст. 1 першого Протокол до Конвенції) і навіть процесуальне право на ефективність судових рішень, що є наслідком гарантії справедливого судового розгляду статті 6 ЄКПЛ.

Наприклад у рішенні в справі «Vrbica v. Croatia» про яке вищезазначалось, ССПЛ повторив, що неможливість отримати остаточне рішення на користь заявника $є$ втручанням у право на мирне володіння майном, яке передбачене ч. 1 ст. 1 Першого протоколу до ЄКПЛ. За цих обставин ЄСПЛ вказав, що у цій справі і відбулося втручання у право заявника на мирне користування його «майном». Зокрема ЄСПЛ дійшов висновку, що відбулось таке з прийняття рішення національним судом, яким було визнано примусове стягнення за визнаним рішенням іноземного суду як недопустимим для заявника, яке було несумісним із принципом законності, а тому суперечить ч. 1 ст. 1 Першого протоколу до ЄКПЛ ${ }^{4}$.

Окрім цього, визнання та виконання рішень іноземних судів може розглядатись ЄСПЛ не лише із застосовуванням п.1 ст. 6 ЄКПЛ, а із ст. 13 ЄКПЛ, яка передбачає право на ефективний засіб юридичного захисту, у випадках порушення права на виконання рішення іноземного суду у розумний строк. Однак судової практики ЄСПЛ щодо застосування положень ст. 13 ЄКПЛ до процедури визнання та виконання рішень іноземних судів $\epsilon$ непоширеною, так як більшість розглянутих справ ЄСПЛ стосувалось проблемі порушення розумного строку судового розгляду та виконання рішень національних судів. Можна навести з цього як приклад рішення у справі «Kudla v. Poland», де ЄСПЛ зробив висновок про порушення статті 13 ЄКПЛ - в тому сенсі, що заявник не мав національних засобів правового захисту, щоб забезпечити дотримання права на «розгляд упродовж розумного строку», яке гарантує пункт 1 статті 6 ЄКПЛ 5 .

\footnotetext{
${ }^{1}$ Europenian Court of Human Right (2007). «Mennesson v. France», app. no. 65192/11, 26 June 2014. <http://hudoc.echr.coe.int/eng?i=001-145389>. (2020, листопад, 11).

${ }^{2}$ Europenian Court of Human Right (2007). «Pini and Others v. Romania», app. no. 78030/01, 22 June 2004.

<http://hudoc.echr.coe.int/eng?i=001-61837>. (2020, листопад, 11).

${ }^{3}$ Europenian Court of Human Right (2007). «Negrepontis-Giannissis v. Greece», app. no. 56759/08, 03 May 2011. <http://hudoc. echr.coe.int/eng?i=001-104678>. (2020, листопад, 11).

${ }^{4}$ Europenian Court of Human Right (2007). «Vrbica v. Croatia», app. no. 32540/02, 01 April 2010.

<http://hudoc.echr.coe.int/eng?i=001-98057>. (2020, листопад, 11).

${ }^{5}$ Europenian Court of Human Right (2007). «Kudla v. Poland», app. no. 30210/96, ECHR 2000-XI.

<http://hudoc.echr.coe.int/eng?i=001-58920>. (2020, листопад, 11).
} 
Разом $з$ тим, право на доступ до суду в аспекті положення п. 1 ст. 6 ЄКПЛ не $є$ абсолютним $\mathrm{i}$ може бути обмеженим також у випадках відмови у визнанні та виконанні рішень іноземних суддів. На думку ЄСПЛ обмеження суперечитиме п. 1 ст. 6 ЄКПЛ, якщо воно не застосовуватиметься з легітимною стороною і якщо не передбачатиме обгрунтованої пропорційності між застосованими засобами та поставленою метою.

Натомість слід наголосити і на випадки правомірної відмови у визнанні та виконанні рішень іноземних судів у розумінні ЄСПЛ. Зокрема у рішенні в справі «McDonald v. France» ${ }^{1}$. ССПЛ визнав правомірну відмову у визнанні рішення суду про розірвання шлюбу, постановленого у Флориді. Така відмова ССПЛ була вмотивованою із посиланням на шахрайство заявника, яке полягало в тому, що заявник навмисно здійснив обхід юрисдикції французьких суддів, так як після отримання відмови у задоволенні позову про розірвання шлюбу у суді Франції, заявник замість оскарження даного рішення, звернувся із аналогічним позовом до американського суду.

У рішенні в справі «Hussin v. Belgium» ССПЛ також визнав правомірною відмову у визнанні та виконанні рішення суду про стягнення аліментів, яке полягало в тому, що заявниця звернулась до суду, який не мав юрисдикції на розгляд ії справи, та як заявником не було дотримано процесуальних правил подачі даної заяви. ЄСПЛ вказав на те, що держава не може нести відповідальність за відмову виконати рішення німецького суду, оскільки заява про визнання та виконання рішення іноземного суду була подана без дотримання національних правил юрисдикції ${ }^{2}$.

3 урахуванням принципу пріоритету застосування норм міжнародного права положення ЄКПЛ та практики ЄСПЛ мають бути орієнтирами для національних органів у сфері забезпечення прав людини.

Сучасні глобалізаційні процеси, впливаючи на всі сфери суспільного життя, не можуть оминути і сферу реалізації судової влади. Тому при проведенні судової реформи та гармонізації процесуального законодавства обов'язково мають враховуватися як прецедентна практика Європейського суду з прав людини ${ }^{3}$.

За сучасних умов і потребує переосмислення значення принципу верховенства права, оскільки слід його оцінювати як певний стандарт судового правотлумачення та правозастосування, що має застосовуватися судами і при розгляді та вирішенні клопотань про визнання та виконання рішень іноземних судів з метою забезпечення права кожного на справедливий судовий розгляд та підвищення ефективності законодавства. Такі складові зазначеного стандарту мають прямо бути взяті із положень ЄКПЛ та практики ЄСПЛ.

Тому з метою реалізації принципу «верховенства права» на сьогодніший день $є$ актуальність застосування положень ЄКПЛ та практики ЄСПЛ як джерела права при розгляді судових справ.

У зв'язку з вищевикладеним і тим, що Україна $є$ державою-членом Ради Свропи, практика ЄСПЛ є однією з основ правозастосування, тому рішення цього Суду слід застосовувати як джерело права під час розгляду клопотань про визнання та виконання рішень іноземних судів в Україні.

Слід також зазначити, що з метою реалізації принципу «верховенства права» відбулось закріплення також на рівні процесуального кодексу застосування положень ЄКПЛ та практики ЄСПЛ як джерела права.

Зокрема, законодавцем 3 цього приводу були внесенні позитивні зміни до Цивільного процесуального Кодексу України щодо застосування положень ЄКПЛ та практики ЄСПЛ як джерела права, а саме у статтю 10, яка передбачає, що суд застосовує при розгляді справ Конвенцію про захист прав людини і основоположних свобод 1950 року і протоколи до неї, згоду на обов'язковість яких надано Верховною Радою України, та практику Європейського суду з прав людини як джерело права ${ }^{4}$.

На думку С. Шевчука, обов'язковість європейського прецедентного права 3 прав людини для України випливає з принципу ієрархії юрисдикцій - Європейському суду з прав людини належить найвища юрисдикція у галузі судового захисту прав та свобод людини, що безпосередньо випливає

\footnotetext{
${ }^{1}$ Europenian Court of Human Right (2007). «McDonald c. France», app. no. 18648/04, 29 April 2004.

<http://hudoc.echr.coe.int/eng?i=001-87756>. (2020, листопад, 11).

${ }^{2}$ Europenian Court of Human Right (2007). «Hussin v. Belgium», app. no. 70807/01, 04 May 2004.

<http://hudoc.echr.coe.int/ eng?i=001-44931>. (2020, листопад, 11).

3 Ткачук, О. С. (2016). Проблеми реалізації судової влади у циивільному судочинстві. Харків: Право, 8-9.

4 Закон про внесення змін до Господарського процесуального кодексу України, Цивільного процесуального кодексу України, Кодексу адміністративного судочинства України та інших законодавчих актів, 2017

(Верховна Рада України). Голос України, 28.11.2017, 221-222.
} 
3 частини четвертої статті 55 Конституції України, незважаючи на те, що діяльність Європейського суду є додатковою, тому що основний «тягар» щодо цього захисту мають узяти на себе національні юрисдикційні органи ${ }^{1}$.

С. П. Головатий на міжнародній конференції «Вплив практики Європейського суду з прав людини на національне конституційне судочинство» (14 жовтня 2005 р., м. Київ) наголосив, що використання рішень ЄСПЛ - це обов'язок національних судів, зокрема України.

Дехто зауважує (наприклад, В. В. Зубар), що самі по собі рішення Суду є для вітчизняних правозастосовчих органів джерелом права, однак практика вирішення окремих судових справ дає можливість зробити певні висновки щодо вдосконалення національного законодавства. Такі рішення

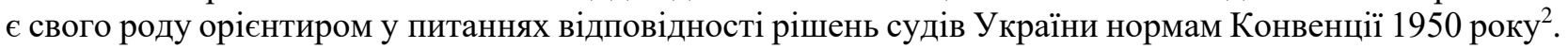

Суди України при розгляді цивільних справ здійснюють посилання у судовому рішенні на положення Конвенції та практику Свропейського суду через статтю 17 Закону України «Про виконання рішень та застосування практики Європейського суду з прав людини» та статтю 10 Цивільного процесуального Кодексу України. Однак на власний розсуд суддя під час ухвалення рішення суду вирішує питання про можливість застосування положень рішень ЄСПЛ.

Окрім цього, прийняті положення дають змогу суддям не тільки прямо посилатися у відповідних судових рішеннях на практику ЄСПЛ, але й зобов'язують законодавчий орган України реформувати чинне законодавство, приводячи його у відповідність до відповідної прецедентної практики ССПЛ.

Тобто під час розгляду справи та тлумаченні положень чинного законодавства України національний суд має використовувати положення ЄКПЛ та практику ЄСПЛ як джерело права.

Iз аналізу судової практики у загальнодоступному реєстрі судових рішень (http://reyestr.court.gov.ua) вбачається, що суди України рідко застосовують судову практики Європейського Суду з прав людини у свої рішеннях при розгляді клопотань про визнання та виконання рішень іноземних судів.

Зокрема була застосовану у таких судових рішеннях, а саме: Харківський апеляційний суд постановою від 14 березня 2019 р. у справі № 629/874/18 залишив ухвалу Лозівського міськрайонного суду Харківської області від 19 грудня 2018 року без змін, якою було визнано та надано дозвіл на примусове виконання в Україні рішення Окружного Суду Фрайзінгу (Федеративна Республіка Німеччина) від 26 липня 2017 року (справа № 4 F 543/16) про передачу А. виключного права щодо визначення місця перебування дитини Б. і передачу дитини їі батьку, обгрунтовуючи своє рішення, колегія суддів приймала до уваги вимоги ст. 17 Закону України «Про виконання рішень та застосування практики Європейського суду з прав людини», відповідно до якої суди застосовують при розгляді справи Конвенцію та практику Суду як джерело права та висновки Свропейського суду 3 прав людини, зазначені в рішенні у справі «Руїс Торіха проти Іспанії» (Ruiz Torija v. Spain) від 9 грудня 1994 року, серія А, № 303А, п. $2958^{3}$.

Київський апеляційний суд постановою від 21 липня 2020 р. у справі № 755/14146/19 ухвалу Дніпровського районного суду м. Києва від 21 січня 2020 року скасував. Постановив нову ухвалу, якою у задоволенні клопотанням суду Першотравневого району міста Мінська Республіки Білорусь та А. про визнання та надання дозволу на примусове виконання рішень суду Першотравневого району міста Мінська Республіки Білорусь від 21 вересня 2018 року відмовлено, обгрунтовуючи своє рішення, колегія суддів приймала до уваги вимоги ст. 17 Закону України «Про виконання рішень та застосування практики Європейського суду з прав людини», відповідно до якої суди застосовують при розгляді справи Конвенцію та практику Суду як джерело права та висновки Європейського суду з прав людини, зазначені в рішенні у справі «Руїс Торіха проти Іспанії» (Ruiz Torija v. Spain) від 9 грудня 1994 року, серія А, № 303А, п. 2958. Суд повторює, що згідно з його усталеною практикою, яка відображає принцип, пов`язаний з належним здійсненням правосуддя, урішеннях судів та інших органів 3 вирішення спорів мають бути належним чином зазначені підстави, на яких вони грунтуються. Хоча пункт 1 статті 6 Конвенції зобов'язує суди обгрунтовувати свої рішення, його не можна тлумачити

\footnotetext{
${ }^{1}$ Шевчук, С. (2007). Судова правотворчість: світовий досвід і перспективи в Украӥні. Київ: Реферат, 173.

2 Українська Гельсінська спілка з прав людини (2009). Практика Європейського суду з прав людини як джерело тлумачення Конвениії 1950 p. <http://helsinki.org.ua/articles/praktyka-evropejskoho-sudu-z-pravlyudyny-yak-dzherelo-tlumachennya-konventsiji-1950-r/>. (2020, листопад, 11).

${ }^{3}$ Єдиний державний реєстр судових рішень (2019). Постанова Харківського апеляційного суду від 14 березня 2019 р. у справі № 629/874/18. <https://reyestr.court.gov.ua/Review/80520076>. (2020, листопад, 11).
} 
як такий, що вимагає детальної відповіді на кожен аргумент. Міра, до якої суд має виконати обов’ язок щодо обгрунтування рішення, може бути різною залежно від характеру рішення ${ }^{1}$.

Дзержинський районний суд міста Харкова ухвалою від 31 серпня 2020 р. у справі № 638/1720/20 відмовив у задоволенні клопотання А. «Про визнання та звернення до виконання рішення іноземного суду - Вищого Суду Каліфорнії (округ Лос-Анжелес, США, справа №19LBFL00640) посилаючись на ч. 4 ст. 10 ЦПК України (суд застосовує при розгляді справ Європейську конвенцію з прав людини і протоколи до неї, згоду на обов'язковість яких надано Верховною Радою України, та практику Європейського суду з прав людини як джерело права), рішення Європейського суду у справі «Хант проти України» від 07.12.2006 року та рішення у справі «М.С. проти України» від 11.07.2017 року².

Київський районний суд міста Харкова ухвалою від 06 листопада 2008 р. у справі № 2к-7/08/12 визнав рішення Дільничного суду зі спадкоємних справ м. Мюнхена з посиланням статтю 17 Закону України «Про виконання та застосування практики Європейського суду з прав людини», п.1 статті 6 Конвенції суди застосовують при розгляді справ Конвенцію та практику Суду як джерело права, та застосувавши рішення Європейського суду у справі «Шмалько проти України» від 20.06.2004 року та рішення у справі «Горнсбі проти Греції» від 19.03.1997 р. п. $40^{3}$.

3 аналізу вказаних судових справ вбачається, що суди України напрацьовують досвід застосування судової практики ЄСПЛ, однак ії застосування неможливе без професіоналізму суддів та правової культури учасників судового розгляду при вирішенні клопотання про визнання та виконання рішень іноземних судів.

Крім цього, за відсутності офіційного перекладу рішення ЄСПЛ неможливим є використання судової практики ЄСПЛ при ухваленні рішень більшістю суддями або ж випадки некваліфікованого тлумачення рішень суду, некваліфікованого перекладу, виривання з контексту окремих, вигідних для тієї чи іншої сторони фактів.

Тому слід погодитись з думкою В. В. Ількова, що при застосуванні національними судами практики ЄСПЛ найбільш важливими питаннями $€$ правильне та точне застосування норм-принципів, які протлумачені Європейським судом з прав людини увідповідному рішенні та можуть бути використані національним судом ${ }^{4}$.

Положення ЄКПЛ та практика ЄСПЛ, які викладені у рішеннях щодо інших держав повинні застосовуватися національними судами як при розгляді судових справ, так і при вирішенні питання про визнання та виконання рішень іноземних судів. Це унеможливить порушення основоположних прав громадян і юридичних осіб, та відповідно для подальших звернень до ЄСПЛ та прийняття ним рішень, ухваленими проти нашої держави.

Зокрема, необхідно проаналізувати та врахувати наведені вище рішення Європейського суду 3 прав людини, у яких Судом звернуто увагу на основних положеннях ЄКПЛ, дотримання яких $€$ обов'язковим не лише при розгляді справ національними судами, але й при вирішенні питання про визнання та виконання рішень іноземних судів, серед яких розумність строку розгляду, гласність, публічність, пропорційність, право на правову допомогу та інші.

На нашу думку слід застосовувати положення ЄКПЛ, а відповідно і практику ЄСПЛ до процедури визнання та виконання рішень іноземних судів в Україні для подальшого вдосконалення на законодавчому рівні механізму визнання та виконання рішень іноземних судів, а також для гармонізації положень національного законодавства із міжнародними стандартами.

\section{References:}

1. Antsupova, T. (2013). Zabezpechennya poslidovnosti pretsedentnoho prava Yevropeyskoho sudu z prav lyudyny: rol Velykoyi palaty [Ensuring the consistency of the case law of the European Court of Human Rights: the role of the Grand Chamber]. Pravo Ukrayiny [Law of Ukraine], 10, 162-169. [in Ukrainian].

2. Europenian Court of Human Right (1997). «Hornsby v. Greece», 19 March 1997, par. 40, Reports of Judgements and Decisions 1997-II <http://hudoc.echr.coe.int/eng?i=001-58020>. (2020, November, 11). [in English].

\footnotetext{
${ }^{1}$ Сдиний державний реєстр судових рішень (2020). Постанова Київського апеляиійного суду від 21 липня 2020 p. у справі № 755/14146/19. <https://reyestr.court.gov.ua/Review/90562632>. (2020, листопад, 11).

${ }^{2}$ Єдиний державний реєстр судових рішень (2020). Ухвала Дзержинського районного суду міста Харкова від 31 серпня 2020 р. у справі № 638/1720/20. <https://reyestr.court.gov.ua/Review/91253498>. (2020, листопад, 11).

${ }^{3}$ Сдиний державний реєстр судових рішень (2008). Ухвала Київського районного суду міста Харкова від 06 листопада 2008 р. у справі № 2к-7/08/12. <https://reyestr.court.gov.ua/Review/3971157>. (2020, листопад, 11). ${ }^{4}$ Ільков, В. В. (2017). Практика Європейського суду з прав людини як джерело права у адміністративному судочинстві: загальні засади. Наме право, 2, 88.
} 
3. Europenian Court of Human Right (2001). «Pellegrini v. Italy», 20 July 2001, Reports of Judgments and Decisions 2001-VIII. <http://hudoc.echr.coe.int/eng?i=001-59604>. (2020, November, 11). [in English].

4. Europenian Court of Human Right (2004). «McDonald c. France», app. no. 18648/04, 29 April 2004. <http://hudoc.echr.coe.int/eng?i=001-87756>. (2020, November, 11). [in English].

5. Europenian Court of Human Right (2007). «Hussin v. Belgium», app. no. 70807/01, 04 May 2004. <http://hudoc.echr.coe.int/ eng?i=001-44931>. (2020, November, 11). [in English].

6. Europenian Court of Human Right (2007). «Kudla v. Poland», app. no. 30210/96, ECHR 2000-XI. $<$ http://hudoc.echr.coe.int/eng?i=001-58920>. (2020, November, 11). [in English].

7. Europenian Court of Human Right (2007). «McDonald c. France», app. no. 18648/04, 29 April 2004. <http://hudoc.echr.coe.int/eng?i=001-87756>. (2020, November, 11). [in English].

8. Europenian Court of Human Right (2007). «Mennesson v. France», app. no. 65192/11, 26 June 2014. <http://hudoc.echr.coe.int/eng?i=001-145389>. (2020, November, 11). [in English].

9. Europenian Court of Human Right (2007). «Negrepontis-Giannissis v. Greece», app. no. 56759/08, 03 May 2011. <http://hudoc. echr.coe.int/eng?i=001-104678>. (2020, листопад, 11).

10. Europenian Court of Human Right (2007). «Pini and Others v. Romania», app. no. 78030/01, 22 June 2004. <http://hudoc.echr.coe.int/eng?i=001-61837>. (2020, November, 11). [in English].

11. Europenian Court of Human Right (2007). «Šneersone and Kampanella v. Italy», app. no. 14737/09, 12 July 2011. <http://hudoc.echr.coe.int/rus?i=001-105624>. (2020, November, 11). [in English].

12. Europenian Court of Human Right (2007). «Vrbica v. Croatia», app. no. 32540/02, 01 April 2010. <http://hudoc.echr.coe.int/eng?i=001-98057>. (2020, November, 11). [in English].

13. Europenian Court of Human Right (2007). «Wagner and J. M. W. L. v. Luxemburg», app. no. 76240/01, 28 June 2007. <http://hudoc.echr.coe.int/eng?i=001-81328>. (2020, November, 11). [in English].

14. Europenian Court of Human Right (2007). «Xv. Latvia» app. no.27853/09, 26 November 2013. <http://hudoc.echr.coe.int/eng?i=001-138992>. (2020, November, 11). [in English].

15. Europenian Court of Human Right (2010). «Jovanoski v. the Former Yugoslav Republic of Macedonia", app. no. 31731/03, 07 January 2010. <http://hudoc.echr.coe.int/eng?i=001-96603>. (2020, November, 11). [in English].

16. Europenian Court of Human Right (2010). «K. v. Italy», app. no. 38805/97, 20 July 2004. <http://hudoc.echr.coe.int/eng?i=001-61924>. (2020, November, 11). [in English].

17. Europenian Court of Human Right (2010). «Regent Company v. Ukraine», no. 773/03, 03 April 2008. <http://hudoc.echr.coe.int/eng?i=001-85681>. (2020, November, 11). [in English].

18. Europenian Court of Human Right (2010). «Romanczyk c. France», app. no. 7618/05, 18 November 2010. <http://hudoc.echr.coe. int/eng?i=001-101763>. (2020, November, 11). [in English].

19. Europenian Court of Human Right (2010). «Saccoccia v. Austria», app. no. 69917/01, 18 December 2008. <http://hudoc.echr.coe.int/eng?i=001-90342>. (2020, November, 11). [in English].

20. Europenian Court of Human Right (2010). «Vrbica v. Croatia», app. no. 32540/02, 01 April 2010. <http://hudoc.echr.coe.int/eng?i=001-98057>. (2020, November, 11). [in English].

21. Europenian Court of Human Right (2013). «Matrakas and Others v. Poland and Greece», app. no. 47268/06, 07 November 2013. <http://hudoc.echr.coe.int/eng?i=001-127812>. (2020, November, 11). [in English].

22. Ilkov, V. V. (2017). Praktyka Yevropeyskoho sudu z prav lyudyny yak dzherelo prava u administratyvnomu sudochynstvi: zahalni zasady [The case law of the European Court of Human Rights as a source of law in administrative proceedings: general principles]. Nashe pravo [Our law], 2, 83-89. [in Ukrainian].

23. Khrystova, H. O. (2013). Doktryna pozytyvnykh zobovyazan derzhavy shchodo prav lyudyny: osnovni etapy formuvannya [The doctrine of positive obligations of the state to human rights: the main stages of formation]. Derzhavne budivnytstvo ta mistseve samovryaduvannya [State building and local self-government], 26. 22. [in Ukrainian].

24. Lutkovska, V. V. (2006). Zastosuvannya vymoh Konventsiyi «Pro zakhyst prav i osnovnykh svobod lyudyny do protsesu vykonannya rishen natsionalnykh sudiv» [Application of the requirements of the Convention for the Protection of Human Rights and Fundamental Freedoms to the process of enforcement of decisions of national courts]. Visnyk tsentru suddivskykh studiy [Bulletin of the Center for Judicial Studies]. <http://www.judges.org.ua/article/Vesnik7_8.pdf>. (2020, November, 11). [in Ukrainian].

25. Shevchuk, S. (2007). Sudova pravotvorchist: svitovyy dosvid i perspektyvy v Ukrayini [Judicial lawmaking: world experience and prospects in Ukraine]. Kyiv: Referat. [in Ukrainian].

26. Tkachuk O. S. (2016). Problemy realizatsiyi sudovoyi vlady u tsyvilnomu sudochynstvi [Problems of judicial power in civil proceedings]. Kharkiv: Pravo. [in Ukrainian].

27. Ukrayinska Helsinska spilka z prav lyudyny (2009) [Ukrainian Helsinki Human Rights Union (2009)]. Praktyka Yevropeyskoho sudu z prav lyudyny yak dzherelo tlumachennya Konventsiyi 1950 [The case law of the European Court of Human Rights as a source of interpretation of the 1950 Convention] <http://helsinki.org.ua/articles/ praktyka-evropejskoho-sudu-z-prav-lyudyny-yak-dzherelo-tlumachennya-konventsiji-1950-r/>. (2020, November, 11). [in Ukrainian].

28. Yedynyy derzhavnyy reyestr sudovykh rishen (2008) [Unified State Register of Judgments (2008)]. Ukhvala Kyivskoho rayonnoho sudu mista Kharkova vid 06 lystopada 2008 r. u spravi № 2k-7/08/12 
[Judgment of the Kyiv District Court of the City of Kharkiv of November 6, 2008 in the case № 2k-7/08/12]. <https://reyestr.court.gov.ua/Review/3971157>. (2020, November, 11). [in Ukrainian].

29. Yedynyy derzhavnyy reyestr sudovykh rishen (2019) [Unified State Register of Judgments (2019)] Postanova Kharkivskoho apelyatsiynoho sudu vid 14 bereznya 2019 r. u spravi № 629/874/18 [Resolution of the Kharkiv Court of Appeal of March 14, 2019 in the case № 629/874/18] <https://reyestr.court.gov.ua/Review/80520076>. (2020, November, 11). [in Ukrainian].

30. Yedynyy derzhavnyy reyestr sudovykh rishen (2020) [Unified State Register of Judgments (2020)]. Postanova Kyivskoho apelyatsiynoho sudu vid 21 lypnya 2020 r. u spravi № 755/14146/19 [Resolution of the Kyiv Court of Appeal of July 21, 2020 in the case № 755/14146/19]. <https://reyestr.court.gov.ua/Review/90562632>. (2020, November, 11). [in Ukrainian].

31. Yedynyy derzhavnyy reyestr sudovykh rishen (2020) [Unified State Register of Judgments (2020)]. Ukhvala Dzerzhynskoho rayonnoho sudu mista Kharkova vid 31 serpnya 2020 r. u spravi № 638/1720/20 [Judgment of the Dzerzhinsky District Court of Kharkiv of August 31, 2020 in the case № 638/1720/20]. <https://reyestr.court.gov.ua/Review/91253498>. (2020, November, 11). [in Ukrainian].

32. Zakon pro vnesennya zmin do Hospodarskoho protsesual'noho kodeksu Ukrayiny, Tsyvilnoho protsesualnoho kodeksu Ukrayiny, Kodeksu administratyvnoho sudochynstva Ukrayiny ta inshykh zakonodavchykh aktiv, 2017 (Verkhovna Rada Ukrayiny) [Law on Amendments to the Commercial Procedural Code of Ukraine, the Civil Procedure Code of Ukraine, the Code of Administrative Procedure of Ukraine and other legislative acts, 2017 (Verkhovna Rada of Ukraine)]. Holos Ukrayiny [Voice of Ukraine], 28.11.2017, 221-222. [in Ukrainian].

33. Zakon pro vykonannya rishen ta zastosuvannya praktyky Yevropeyskoho sudu z prav lyudyny, 2006, St. 260 (Verkhovna Rada Ukrayiny) [Law on Enforcement of Judgments and Application of the Case Law of the European Court of Human Rights, 2006, Art. 260 (Verkhovna Rada of Ukraine)]. Vidomosti Verkhovnoyi Rady Ukrayiny [Information of the Verkhovna Rada of Ukraine], 30. . [in Ukrainian]. 